\title{
Efektivitas Kombinasi Ekstrak Etanol 96\% \\ Daun Insulin (Tithonia diversifolia) dan Daun Sirsak (Annona muricata) Sebagai Antihiperglikemik Pada Mencit Putih Jantan
}

\author{
Novi Fajar Utami ${ }^{1}$, Florensia Ndole Mbete ${ }^{1}$, E Mulyati Effendi ${ }^{2}$ \\ ${ }^{1}$ Program Studi Farmasi, Universitas Pakuan, Bogor, Jawa Barat, Indonesia 16134 \\ ${ }^{1}$ Program Studi Biologi, Universitas Pakuan, Bogor, Jawa Barat, Indonesia 16134 \\ *Email Korespondensi : novi.utami@unpak.ac.id
}

Diterima : 12-Juli-2020Ｄirevisi : 21-September-2020Ｄisetujui : 16-November-2020

Copyright $@ 2020$ Universitas Pakuan

FITOFARMAKA: Jurnal Ilmiah Farmasi is licensed under a

Creative Commons Attribution-ShareAlike 4.0 International License

\begin{abstract}
ABSTRAK
Diabetes melitus (DM) merupakan suatu sindrom klinik yang ditandai dengan poliuri, polidipsi, dan polifagi, disertai peningkatan kadar glukosa darah atau hiperglikemia (glukosa puasa $\geq 126 \mathrm{mg} / \mathrm{dL}$ atau postprandial $\geq 200 \mathrm{mg} / \mathrm{dL}$ atau glukosa sewaktu $\geq 200 \mathrm{mg} / \mathrm{dL}$ ). Indonesia diperkirakan pada tahun 2030 akan memiliki penderita DM sebanyak 21,3 juta jiwa. Obat yang digunakan untuk masyarakat penderita DM saat ini adalah Metformin terbukti memiliki efek samping yaitu flatulensi, mual, diare dan nyeri perut. Penelitian ini bertujuan untuk menguji efektivitas dan menetapkan dosis efektif kombinasi ekstrak etanol 96\% daun insulin dan daun sirsak sebagai antihiperglikemik pada mencit putih jantan yang diinduksi larutan glukosa. Metode penelitian menggunakan 8 kelompok perlakuan dengan masing masing 4 ulangan, yaitu kelompok kontrol positif metformin $(1,3 \mathrm{mg} / 20 \mathrm{~g} \mathrm{BB})$, kontrol negatif (akuades), kontrol normal (pakan), Dosis 1 (ekstrak daun sirsak 2,24 mg/ $20 \mathrm{~g}$ $\mathrm{BB}$ ), Dosis 2 (ekstrak daun insulin 0,7 mg/20 g BB), Dosis 3 (daun insulin 0,7 mg/ $20 \mathrm{~g} \mathrm{BB}$ dan sirsak 2,24 mg/20 g BB), Dosis 4 (daun insulin 0,7 mg/ $20 \mathrm{~g} \mathrm{BB}$ dan 1,12 mg/ $20 \mathrm{~g} \mathrm{BB}$ ), Dosis 5 (daun insulin 0,35 mg/ $20 \mathrm{~g}$ BB dan 2,24 mg/20 g BB). Hasil penelitian menunjukkan bahwa dengan pemberian dosis kombinasi daun insulin $0,7 \mathrm{mg} / 20 \mathrm{~g}$ BB dan daun sirsak 2,24 $\mathrm{mg} / 20 \mathrm{~g} \mathrm{BB}$ terbukti efektif menurunkan kadar gula darah dengan rata rata 93,15 mg/dL. Berdasarkan hasil tersebut dapat disimpulkan bahwa dosis kombinasi daun insulin dan daun sirsak berpotensi menurunkan kadar gula darah.
\end{abstract}

Kata kunci : Antihiperglikemik; TTGO; Daun Sirsak; Daun Insulin

\section{Effectivity of $96 \%$ Ethanol Extract Of Insulin Leaves (Tithonia diversifolia) and Soursop Leaves (Annona muricata) Combination as Antihiperglicemic in White Mice}

\begin{abstract}
Diabetes Mellitus is a clinic syndrome marked by polyuria, polyphagic, polydipsia accompanied by increasing of blood glucose levels or hyperglycemia (fasting glucose $\geq 126$ $\mathrm{mg} / \mathrm{dL}$ atau postprandial $\geq 200 \mathrm{mg} / \mathrm{dL}$ ). It is estimated that by 2030, 21.3 million Indonesians will suffer from DM. The common drug used to treat DM patients which proven to have side effects such as flatulence, nausea, diarrhea and abdominal pain. This study aim was to determine the effectivity of $96 \%$ ethanol extract of insulin leaves and soursop leaves
\end{abstract}


combination as antihyperglycemic on male mice induced with glucose solution. Eight groups of male mice each with 4 replications were used in this study. The positive control group was treated with metformin $(1,3 \mathrm{mg} / 20 \mathrm{~g} / \mathrm{BB})$, negative control (water), normal control (weft), dose 1 ( soursop 2,24 mg/20 g BB), dose 2 (insulin 0,7 mg/20 g BB), dose 3 (insulin 0,7 mg/ $20 \mathrm{~g} \mathrm{BB}$ and soursop 2,24 $\mathrm{mg} / 20 \mathrm{~g} \mathrm{BB}$ ), dose 4 (insulin 0,7 $\mathrm{mg} / 20 \mathrm{~g} \mathrm{BB}$ and soursop 1,12 $\mathrm{mg} / 20 \mathrm{~g} \mathrm{BB}$ ) dose 5 (insulin 0,35 $\mathrm{mg} / 20 \mathrm{~g} \mathrm{BB}$ and soursop 2,24 mg/20 $\mathrm{g} \mathrm{BB}$ ).

The result showed that administration of insulin leaves $0,7 \mathrm{mg} / 20 \mathrm{~g} \mathrm{BB}$ and soursop leaves 2,24 mg/20 g BB combination was effective to reduce blood sugar levels by 95,15 mg/dL. Based on these results it can be concluded that the combination dose of insulin leaves and soursop leaves has the potential to reduce blood sugar levels in mice male.

Keywords : Antihiperglicemic, TTGO, Soursop Leaves, Insulin Leaves

\section{PENDAHULUAN}

Diabetes melitus merupakan suatu sindrom klinik yang ditandai oleh poliuri, polidipsi, dan polifagi, disertai peningkatan kadar glukosa darah atau hiperglikemia (glukosa puasa $\geq 126 \mathrm{mg} / \mathrm{dL}$ atau postprandial $\geq 200 \mathrm{mg} / \mathrm{dL}$ atau glukosa sewaktu $\geq 200 \mathrm{mg} / \mathrm{dL}$ ). Indonesia diperkirakan pada tahun 2030 akan memiliki penderita DM sebanyak 21,3 juta jiwa (Depkes RI, 2013). Salah satu obat sintetik yang dapat digunakan untuk penderita DM adalah metformin, yang terbukti memiliki efek samping yaitu flatulensi (12\%), mual $(14 \%)$, diare $(2 \%)$ dan nyeri perut $(6 \%)$ (Primadianti dkk., 2009).

Alternatif alami dan aman yang dapat digunakan untuk meminimalisir penggunaan obat kimia dan efek samping yaitu dengan menggunakan tanaman obat. Tanaman di Indonesia yang dapat memberikan manfaat sebagai antidiabetes adalah daun insulin (Tithonia diversifolia). Rebusan daun insulin dipercaya berkhasiat dalam mengobati DM (Ronald, 2015). Penelitian Prasetyo dkk, (2016) menyatakan bahwa daun insulin pada tikus mempunyai aktivitas sebagai antidiabetes dengan dosis $250 \mathrm{mg} / \mathrm{KgBB}$ namun masih berbeda nyata dengan kontrol positif (Metformin). Daun insulin memiliki kandungan flavonoid dan seskuiterpen yang mempunyai potensi untuk penurunan kadar gula darah (Sasmita dkk, 2017).

Tanaman obat yang lain yang dapat memberikan manfaat sebagai antidiabetes adalah daun sirsak (Annona muricata).
Daun sirsak dengan dosis $800 \mathrm{mg} / \mathrm{kgBB}$ terhadap tikus memiliki potensi sebagai antidiabetes setara dengan kontrol positif yaitu Glibenklamid (Setyawati dkk., 2015). Penelitian ini bertujuan untuk menguji efektivitas dan menetapkan dosis efektif kombinasi ekstrak etanol $96 \%$ daun insulin dan daun sirsak sebagai antihiperglikemik yang diinduksi larutan glukosa pada mencit putih jantan.

\section{METODE PENELITIAN Alat dan Bahan}

Alat-alat yang digunakan berupa : neraca analitik merk $L a b$ Pro®, ayakan mesh 40, krus, tanur merk Vulcan Pro A550®, oven merk Memmert 53L® Excellent, kandang mencit, kain batis, grinder (Miyako®), sonde lambung, stopwatch, alat pengukur gula darah atau glukometer merk Easy Touch $®$, botol coklat 2,5L, vacuum dryer merk Ogawa®, dan peralatan gelas laboratorium lainnya.

Bahan-bahan yang digunakan terdiri dari daun insulin, daun sirsak, hewan mencit putih (Mus musculus), aquadest, makanan mencit (pellet), sekam serbuk kayu, obat antidiabetik oral (Metformin), glukosa monohidrat, etanol, serbuk magnesium, Asam klorida, Asam Sulfat, pereaksi Dragendorff, pereaksi Mayer, Natrium klorida, gelatin, Besi (III) klorida.

\section{Pembuatan Simplisia Daun Sirsak dan Daun Insulin}


Tanaman insulin dan sirsak diperoleh dari Kota Bogor. Bagian yang digunakan adalah seluruh bagian daun tua pekat sebanyak $2 \mathrm{~kg}$. Daun kemudian dikumpulkan dan dilakukan sortasi basah pada sehingga dapat dibersihkan dari pengotor menempel pada daun, proses pencucian dilakukan dengan menggunakan air bersih yang mengalir hingga bersih, kemudian ditiriskan dengan cara dianginanginkan yang bertujuan untuk membebaskan daun dari sisa-sisa air selama proses pencucian. Proses pengeringan menggunakan oven dengan suhu $50-55^{\circ} \mathrm{C}$ di Laboratorium Universitas Pakuan. Simplisia kering selanjutnya melewati proses sortasi kering yang bertujuan untuk memisahkan benda asing atau pengotor lainnya selama proses pengeringan dan adanya daun yang rusak dikarenakan pemanasan. Tahap berikutnya simplisia di grinder sehingga menjadi simplisia serbuk dan diayak dengan ayakan mesh 40 .

\section{Penetapan Kadar Air}

Penetapan kadar air dilakukan dengan menggunakan metode gravimetri ditimbang sebanyak $2 \mathrm{~g}$ simplisia, kemudian dimasukkan ke dalam cawan penguap yang sebelumnya telah ditara terlebih dahulu, lalu dimasukkan ke dalam oven dengan suhu $105^{\circ} \mathrm{C}$ selama 3-5 jam, kemudian didinginkan lalu ditimbang, dilanjutkan setelah 1 jam sampai berat 2 penimbangan terakhir tidak lebih dari $0,25 \%$.(DepKes RI, 2000).

\section{Penetapan Kadar Abu}

Ditimbang $2 \mathrm{~g}$ simplisia, dan dimasukkan ke dalam krus. Dipijarkan dengan suhu $\pm 600^{\circ} \mathrm{C}$ perlahan lahan hingga arang habis ditandai serbuk ditandai serbuk berwarna putih atau abu, didinginkan lalu ditimbang hingga bobot tidak lebih dari $0,25 \%$. Dilakukan pengulangan 2 kali (duplo) caranya yaitu dengan memasukkan krus ke dalam tanur secara bersamaan (Depkes RI, 2000).

\section{Pembuatan Ekstrak Daun Insulin dan Daun Sirsak}

Simplisia daun insulin dan daun sirsak diekstraksi dengan menggunakan maserasi. Pelarut yang digunakan adalah etanol 96\%. Simplisia serbuk daun insulin dan daun sirsak ditimbang masing masing $500 \mathrm{~g}$ direndam menggunakan pelarut etanol 96\% dengan perbandingan (1:10) sebanyak 5 L (dibagi menjadi 3 hari) pada hari pertama direndam etanol sebanyak $2 \mathrm{~L}$, hari kedua 1,5 L dan hari ketiga 1,5L kemudian dienaptuangkan. Maserat dipisahkan dengan cara filtrasi. Semua maserat dikumpulkan, kemudian dikeringkan menggunakan alat vacuum dryer terbentuk ekstrak kering (Hanani, 2015).

\section{Uji Fitokimia Simplisia dan Ekstrak Daun Sirsak dan Daun Insulin}

Uji fitokimia yang dilakukan untuk mengidentifikasi senyawa aktif yang terdapat dalam ekstrak tersebut. Uji fitokimia meliputi uji flavonoid, tanin, saponin, dan alkaloid (Hanani, 2015).

\section{Aklimatisasi Hewan Coba}

Sebelum dilakukan penelitian, dilakukan kaji etik terlebih dahulu di Fakultas Matematika dan Ilmu Pengetahuan Alam Universitas Pakuan Bogor dengan nomor SK 59/KEPHP-UNPAK/9-2019 kemudian aklimatisasi hewan coba berupa mencit putih jantan (Mus musculus) sebanyak 32 ekor yang digunakan pada penelitian ini. Terlebih dahulu hewan coba ditimbang kemudian dihitung Coefficient of Variation (CV) untuk mengetahui kehomogenan, hewan coba masih dapat dinyatakan homogen bila CV $<15 \%$ (Nasution, 2009). Selanjutnya dibagi secara acak menjadi 8 kelompok perlakuan yang setiap kelompoknya terdiri dari 4 ekor sebagai ulangan kemudian diadaptasikan selama 7 hari dalam kandang, diberi makan dan minum secara ad libitum. 
Uji Aktivitas Antihiperglikemik Menggunakan Metode Test Toleransi Glukosa Oral (TTGO)

1. Hewan percobaan yang digunakan dalam penelitian ini mencit jantan sebanyak 32 ekor dengan berat mencit berkisar antara 20-30 g. Hewan percobaan diaklimatisasi terlebih dahulu selama 7 hari. Hewan uji dikelompokkan secara acak dibagi dalam 8 kelompok dengan masing masing kelompok 4 ulangan dilakukan penimbangan bobot badan awal untuk semua hewan uji sebelum dilakukan pengujian. Setelah dipuasakan selama 10-12 jam, lalu diukur kadar glukosa darah tikus dengan mengambil sampel darah dari vena ekor untuk penentuan kadar glukosa awal $\left(\mathrm{t}_{0}\right)$.

2. Hewan uji di induksi dengan larutan glukosa $0,13 \mathrm{~g} / \mathrm{BB}$ secara oral, kemudian 30 menit kemudian diberi sediaan uji berdasarkan kelompok uji. Kelompok Kontrol Negatif K(-) diberi akuades, Kelompok Kontrol Positif K(+) diberi metformin $1,3 \mathrm{mg} / \mathrm{g}$ BB. Kelompok uji dosis tunggal diberi 0,7 $\mathrm{mg} / 20 \mathrm{~g}$ BB ekstrak tunggal daun insulin dan ekstrak tunggal daun sirsak 2,24 $\mathrm{mg} / 20$ g BB. Kelompok uji dosis kombinasi 1:1 diberi $0,7 \mathrm{mg} / 20 \mathrm{~g}$ BB ekstrak daun insulin dan $2,24 \mathrm{mg} / 20 \mathrm{~g}$ BB ekstrak daun sirsak. Kelompok uji dosis kombinasi 1 : 0,5 diberi $0,7 \mathrm{mg} / 20$ g BB ekstrak daun insulin dan 1,12 $\mathrm{mg} / 20 \mathrm{~g}$ BB ekstrak daun sirsak. Kelompok uji dosis kombinasi 0,5:1 diberi $0,35 \mathrm{mg} / 20 \mathrm{~g}$ BB ekstrak daun insulin dan 2,24 mg/20 g BB ekstrak daun sirsak. Selanjutnya kadar glukosa darah diukur selama periode waktu menit ke-30, ke-60 ,ke-90, ke-120 setelah induksi dengan menggunakan glukometer easytouch.

3. Data yang diperoleh dianalisis dengan analisis sidik ragam rancangan acak lengkap (RAK) dengan menggunakan program SPSS

\section{Pengukuran Kadar Gula Darah Tikus}

Pengukuran kadar gula darah tikus diukur pada menit ke-0, ke-30, ke-60, ke-90, ke-120. Pengukuran kadar gula darah dilakukan setelah tikus dipuasakan selama 10-12 jam, cuplikan berupa darah diambil melalui pembuluh darah vena pada ekor tikus, kadar gula darah diukur menggunakan alat glukometer Easy Touch®. Kadar gula darah dinyatakan $\mathrm{mg} / \mathrm{dL}$.

\section{Analisis Data}

Untuk mendapatkan suatu kesimpulan dari penelitian ini, data yang diperoleh dianalisis dengan analisis sidik ragam rancangan acak lengkap (RAK) dengan menggunakan program SPSS. Faktor perlakuan pertama adalah dosis yang terdiri dari 8 dosis dan faktor perlakuan kedua adalah lama pemberian yang terdiri dari 5 lama pemberian.

\section{HASIL DAN PEMBAHASAN \\ Hasil Pembuatan Ekstrak Daun Insulin dan Daun Sirsak}

Serbuk simplisia daun sirsak dan daun insulin selanjutnya di ekstraksi dengan metode maserasi karena metode maserasi dapat menghasilkan senyawa flavonoid yang optimum (Damar dkk., 2014) dan pelarut yang digunakan untuk ekstraksi adalah etanol $96 \%$. Menurut penelitian Senja (2014) pelarut etanol 96\% dapat menghasilkan persentase rendemen yang tinggi dan memberikan perlindungan terhadap kontaminasi mikroba selama pembuatan ekstrak karena kandungan air sedikit (Yulia, 2006). Tahapan selanjutnya maserat dikumpulkan kemudian dilakukan pengeringan menggunakan vacuum dryer untuk mendapatkan ekstrak kental.

\section{Penetapan Kadar Air Serbuk dan Ekstrak Daun Sirsak dan Daun Insulin}

Kadar air merupakan salah satu standarisasi simplisia. Adanya air dalam simplisia tanaman obat atau dalam serbuk dan ekstrak akan memungkinkan 
tumbuhnya mikroba. Hasil penetapan kadar air serbuk simplisia daun insulin 8,03\% dan hasil penetapan kadar air simplisia serbuk daun sirsak 8,22\%. Hasil ini memenuhi persyaratan yaitu tidak lebih dari $10 \%$ (DepKes RI, 2000).

Hasil perhitungan rata-rata kadar air ekstrak daun insulin 4,55\% dan ekstrak daun insulin 4,55\%. Hasil ini memenuhi persyaratan yaitu tidak lebih dari $10 \%$ (DepKes RI, 2000).

Penetapan Kadar Abu Serbuk dan Ekstrak Daun Insulin dan Daun Sirsak

Penentuan kadar abu adalah bahan dipanaskan pada temperatur senyawa organik (debu, kerikil, dan pasir) dan turunannya terdekstruksi menguap. Sehingga tersisa unsur mineral dan anorganik, yang memberikan gambaran kandungan mineral internal dan eksternal $(\mathrm{Fe}, \mathrm{Zn}, \mathrm{Na}$ dan $\mathrm{Cl})$ yang berawal dari proses awal sampai terbentuknya ekstrak atau simplisia.( Depkes RI, 2000)

Hasil penetapan kadar abu pada serbuk simplisia daun insulin 5,90\% dan serbuk simplisia daun sirsak 5,74\%. Hasil penetapan kadar abu ekstrak daun insulin 4,60\% dan penetapan kadar abu ekstrak daun sirsak 4,47\%. Hasil ini memenuhi persyaratan yaitu tidak lebih dari $8 \%$ (DepKes RI, 2000).

\section{Hasil Uji Fitokimia Serbuk dan Ekstrak Daun Insulin dan Daun Sirsak}

Hasil uji fitokimia daun insulin mengandung senyawa alkaloid, flavonoid, tanin, saponin hasil tersebut sesuai dengan penelitian Purba (2013) yang menyatakan bahwa daun insulin mengandung senyawa alkaloid, tanin, saponin, dan flavonoid.

\section{Hasil Uji Aktivitas Antihiperglikemik menggunakan metode Tes Toleransi Glukosa Oral (TTGO)}

Pemberian perlakuan pada hewan coba terlebih dahulu dilakukan kaji etik di Fakultas Matematika dan Ilmu pengetahuan
Alam Universitas Pakuan Bogor dan telah lolos kaji etik dengan nomor etik. Untuk mendapatkan hasil data yang akurat, maka dilakukan perhitungan CV (Coefficient variant) berdasarkan bobot badan baru dilakukan aklimatisasi pada hewan coba tersebut. Berdasarkan hasil perhitungan yang didapatkan nilai CV sebesar 8,36\%, sehingga dapat dinyatakan hewan coba yang digunakan relatif homogen karena CV $<15 \%$ (Nasution, 2009).

Penelitian ini menggunakan metode Tes Toleransi Glukosa Oral (TTGO) dengan memberikan induksi beban glukosa dengan konsentrasi larutan glukosa yang digunakan adalah $0,13 \mathrm{~g} / \mathrm{kg}$ BB. Mencit normal induksi hiperglikemia dengan pemberian glukosa tinggi untuk meningkatkan kadar gula darah yang bersifatnya sementara pada menit ke 0 . Metode ini bertujuan untuk mengetahui kemampuan tubuh mentoleransi pemberian larutan glukosa sehingga dapat diketahui adanya pengaruh pemberian perlakuan dosis dengan melihat kurva toleransi glukosa oral (Atmojo dkk., 2016).

Berdasarkan rata rata kadar gula darah dosis insulin : sirsak $(1: 1)$ yaitu $0,7 \mathrm{mg} / 20$ gBB dan 2,24 mg/20 gBB memiliki penurunan kadar gula darah yang paling rendah yaitu 93,15 $\mathrm{mg} / \mathrm{dL}$, dibandingkan dosis kombinasi lain nya. Dan pada dosis insulin : sirsak $(0,5: 1)(0,35 \mathrm{mg} / 20 \mathrm{gBB}$ dan $2,24 \mathrm{mg} / 20 \mathrm{gBB}$ ) memiliki rata rata kadar gula darah 98,05 mg/dL lebih baik bandingkan dengan kontrol positif (metformin) yang rata rata kadar gula darah sebesar 111,15 mg/dL, kontrol negatif memiliki rata rata kadar gula darah lebih tinggi 190,30 mg/dL dan pada kontrol normal memiliki rata rata kadar gula darah $68,1 \mathrm{mg} / \mathrm{dL}$. Setelah dilakukan analisis data dengan menggunakan RAK. Berdasarkan uji ANOVA menunjukkan bahwa perlakuan (dosis) memberikan pengaruh yang nyata terhadap penurunan kadar gula pada mencit yang hiperglikemia.

Perbedaan antar perlakuan dilakukan uji lanjut DUNCAN. Pada kontrol positif 
(Metformin), dosis insulin : sirsak $(1: 1)$ $(0,7 \mathrm{mg} / 20 \mathrm{gBB}$ dan $2,24 \mathrm{mg} / 20 \mathrm{gBB})$, dosis insulin : sirsak (1:0.5) $(0,7 \mathrm{mg} / 20 \mathrm{gBB}$ dan $1,12 \mathrm{mg} / 20 \mathrm{gBB})$ dan dosis insulin : sirsak $(0,5: 1)(0,35 \mathrm{mg} / 20 \mathrm{gBB}$ dan 2,24 $\mathrm{mg} / 20 \mathrm{gBB}$ ) memiliki pengaruh yang sama terhadap penurunan kadar gula darah, dan berbeda dengan kontrol negatif (air) dan kontrol normal terhadap penurunan kadar gula darah, dosis yang paling efektif untuk menurunkan kadar gula darah berdasarkan uji lanjut DUNCAN kadar gula darah adalah dosis insulin : sirsak $(1: 1)(0,7 \mathrm{mg} / 20 \mathrm{gBB}$ dan 2,24 mg/20 gBB) karena memiliki rata rata penurunan kadar gula darah yang paling rendah dibandingkan dengan dosis kombinasi lainnya. Hasil pengukuran kadar gula darah dapat dilihat pada Grafik 1.

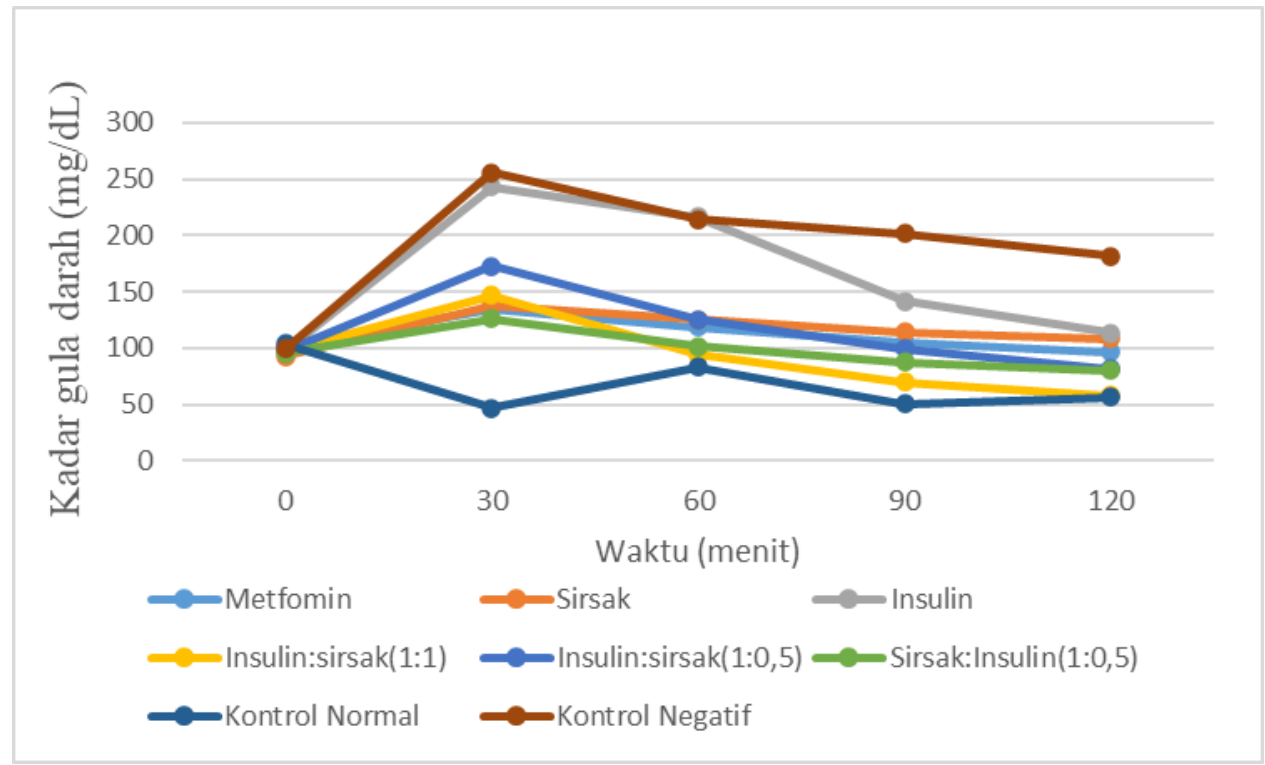

Grafik 1. Pengukuran Kadar Gula Darah

Berdasarkan grafik di atas pada menit ke-0, kadar glukosa darah normal tidak lebih dari $126 \mathrm{mg} / \mathrm{dL}$ (glukosa darah puasa) (Perkeni, 2011), kemudian pada menit ke 30 diinduksi glukosa dan diamati kadar gula darah melebihi normal. Hal ini diduga karena disebabkan pengambilan glukosa sel B pankreas yang difasilitasi oleh glucose transporter (GLUT 2) transporter glukosa tipe 2, terjadi penurunan kadar gula darah pada menit 90-120 karena peningkatan insulin yang dapat menyebabkan penurunan glukosa darah puasa (Agnia, 2016).

Aktivitas kombinasi ekstrak daun insulin dan daun sirsak terbukti mampu menurunkan kadar gula darah pada mencit. Senyawa aktif yang terdapat dalam daun insulin adalah flavonoid yang merupakan senyawa polifenol untuk menurunkan kadar gula darah dan menghambat alfa enzim glukosidase dan enzim amilase sehingga pemecahan karbohidrat menjadi monosakarida menjadi gagal dan glukosa tidak dapat diserap oleh usus yang menyebabkan terjadi penurunan kadar glukosa dalam darah (Baroni et al., 2008).

Senyawa aktif daun sirsak yang mampu menurunkan kadar glukosa darah adalah flavonoid dan tanin. Flavonoid memiliki efek hipoglikemik dengan mekanisme yaitu merangsang pelepasan insulin yang bertindak seperti insulin, meningkatkan glukosa oleh jaringan perifer serta mengatur enzim enzim yang berperan dalam metabolisme karbohidrat (Brachmachari, 2011). Salah satu jenis flavonoid yaitu quercetin mampu menurunkan kadar gula darah dengan mekanisme inhibitor transpor glukosa oleh intestinal GLUT 2 dan GLUT 5 yang 
bertanggung jawab didalam usus halus (Wulandari, 2010). Tanin juga dapat menurunkan kadar gula darah dengan meningkatkan aktivitas glukosa melalui aktivasi MAPK (Mitogen-Activated Protein Kinase) dan PI3K (Phosphoinositide 3Kinase) (Kumari dkk., 2012).

\section{KESIMPULAN}

Dari hasil penelitian diatas dapat disimpulkan bahwa :

1. Dosis kombinasi daun insulin dan daun sirsak berpotensi menurunkan kadar gula darah.

2. Dosis kombinasi daun insulin 0,7 $\mathrm{mg} / 20 \mathrm{~g}$ BB dan daun sirsak $(2,24$ $\mathrm{mg} / 20 \mathrm{~g} \quad \mathrm{BB}$ terbukti efektif menurunkan kadar gula darah dengan rata rata $93,15 \mathrm{mg} / \mathrm{dL}$.

\section{DAFTAR PUSTAKA}

Agnia, A. (2015). Efek ekstrak daun insulin (Smallanthus sonchifolius) terhadap kadar glukosa darah, berat badan dan low density lipoprotein pada tikus yang diinduksi streptozotocin. Skripsi. Fakultas Kedokteran dan Ilmu Kesehatan UIN SYARIF HIDAYATULLAH.

Atmojo, R. D., Arifian, H., Ibrahim, A., \& Rusli, R. (2016). Aktivitas penurunan gula darah kombinasi ekstrak daun kumis kucing (Orthosiphon aristatus) dan daun insulin (Tithonia diversifolia) terhadap mencit (Mus musculus). Prosiding Seminar Nasional Kefarmasian Ke-4 Samarinda. Universitas Mulawarman Samarinda Kalimantan Timur.

Baroni S., Suzuki-Kemmelmeier F., Caparroz-Assef S.M., Cuman R.K.N. \& Bersani-Amado C.A. (2008). Effect of crude extracts of leaves of smallanthus sonchifolius (yacon) on glycemia in diabetic rats. Brasileira de Ciências Farmacêuticas, 44 (3), 521-530.
Brachmachari, G. (2011). Bioflavonoids with promising antidiabetic potentials. A critical Survey Opportunity, Challenge and Scope of Natural Products in Medicinal Chemistry. 187-212.

Damar,A.C., Max,R.J.R. \& Defny,S.W. (2014). Kandungan flavonoid dan aktivitas antioksidan dan total ekstrak etanol daun kayu kapur (Melanolepsis multiglandulosa Reinchf). Pharmacon Jurnal Ilmiah Farmasi. Vol.3 (4): 12; 15-16; 18.

Darmawi, R. A., Chairul, S. \& Rudi, K. (2015). Aktivitas antihiperglikemik dari ekstrak etanol dan n-Heksana daun kembang bulan (Tithonia diversifolia A. Gray) pada tikus putih jantan. Jurnal Kimia Mulawarman. Vol 2. No 12.

Departemen Kesehatan Republik Indonesia RI. (2000). Parameter Standar Umum Ekstrak Tumbuhan Obat. Jakarta: Direktorat Jendral POM.

Departemen Kesehatan Republik Indonesia RI. (2013). Diabetes melitus Penyebab Kematian Nomor $6 \mathrm{Di}$ Dunia. Jakarta: Departemen Kesehatan.

Hanani, E. (2015). Analisis Fitokimia. Jakarta: EGC.

Kumari, M., \& Jain, J. (2012). An antinutrient with positive effect to manage diabetes. Res. J. Recent Sci. 12: 70-73.

Nasution, N. (2009). Metode Research (Penelitian Ilmiah). Jakarta: Bumi Aksara

Prasetyo, A., Grhanesia, T., Sekar, W. \& In'am, M. (2016). Perbandingan efek hipoglikemik infusa daun kembang bulan (Tithonia diversifolia (Hamsley) A. Gray) dan metformin pada tikus yang diinduksi aloksan. Vol 43 (2).

Primadianti, A., \& Andayani, T, M. (2009). Analisis efektif biaya penggunaan insulin vs insulin metformin pada 
pasien dm tipe- 2. Jurnal Farmasi Indonesia. 4(3).

Ronald, P., Hutahea., S. \& Ilyas, S. (2015). Uji antihiperglikemia ekstrak etanol daun kembang bulan (Tithonia diversifolia) Pada Mencit (Mus musculus) yang diinduksi diabetes dengan aloksan. Jurnal Biosains. 1(2).

Sasmita, F, W., Susetyarini, E., Husamah. \& Pantiwati, Y. (2017). Efek ekstrak daun kembang bulan (Tithonia diversifolia) terhadap kadar glukosa darah tikus wistar (Rattus norvegicus) yang diinduksi alloxan. Biosfera. 34 (1): 22-31.

Senja,Y., Ellisa, S., Kharis, N. \& Prawita, S. (2014). Perbandingan Metode Ekstraksi dan Variasi Pelarut Terhadap Rendemen dan Aktivitas Antioksidan Ekstrak Kubis Ungu (Brassica oleracea). Trad. Med. J. 19(1): 43-48.
Setyawati, T. \& Nurjannah, A. (2015). Manfaat ekstrak daun sirsak (Annona muricata) sebagai antihiperglikemia pada tikus wistar diabetik induksi aloksan. Jurnal Ilmiah kedokteran, 2 (1).

Wulandari, C.E. (2010). Pengaruh Pemberian Ekstrak Bawang Merah (Allium ascalonicum) Terhadap Penurunan Kadar Glukosa Darah Pada Tikus Wistar Dengan Hiperglikemia. Skripsi._Universitas Diponegoro Semarang.

Yulia, R. (2006). Kandungan Tanin dan Potensi Anti Streptococcus mutans Daun Teh var. Assamica Pada Berbagai Tahap Pengolahan. Skripsi. Fakultas Matematika dan Ilmu Pengetahuan Alam. Institut Pertanian Bogor. 